GEOLOGICA BALCANICA, 48 (3), Sofia, Dec. 2019, pp. 35-41.

\title{
Cliff erosion - mapping, causes and effects in the coastal zone near Cape Kaliakra (northern Bulgarian Black Sea)
}

\author{
Plamen Ivanov, Rosen Nankin, Miroslav Krastanov \\ Geological Institute, Bulgarian Academy of Sciences, Acad. G. Bonchev Str., Bl. 24, 1113 Sofia, Bulgaria; \\ e-mails: plivanov62@geology.bas.bg; nankin_r@abv.bg; miro_k@geology.bas.bg \\ (Accepted in revised form: December 2019)
}

\begin{abstract}
The study covers the coastal slope in the Zelenka locality (northern Bulgarian Black Sea coast). This is a beautiful but also dangerous area due to constant sloping and falling of huge blocks of land on the shore. The slope is composed of Miocene sediments: diatomaceous clays (Euxinograd Formation), unconsolidated aragonite sediments with limestone interbeds (Topola Formation), and a steep limestone rock crown (Karvuna Formation). An assessment of the material eroded from the slope, composed of aragonite sediments of the Topola Formation, for the period from October 2018 to March 2019 was made. The quantities of this material were measured and laboratory tests were carried out on the aragonite sediments. The grain size and plasticity (classification characteristics) of the soil were determined. The surface of the slope is waterlogged (or wet), as water flows down the slope of the contact formed between the Topola and Karvuna formations. The geotechnical studies and mapping of the coastal slope revealed that the erosion processes can affect not only the slope stability, but also of the road integrity, and therefore may pose a real geological risk.
\end{abstract}

Ivanov, P., Nankin, R., Krastanov, M. 2019. Cliff erosion - mapping causes and effects in the coastal zone near Cape Kaliakra (northern Bulgarian Black Sea). Geologica Balcanica 48 (3), 35-41.

Keywords: erosion, landslides, aragonite sediments, coastal zone, Cape Kaliakra, Black Sea Coast.

\section{INTRODUCTION}

Coastal cliff erosion is increasingly posing serious geological risks for coastal areas. Cliff erosion processes can cause significant issues for public safety, cultural and natural landmarks, and infrastructure. This is particularly concerning in northern Bulgarian Black Sea coast as cliffs make up more than 60 percent of the coastline. This study deals with the sea-facing slope along the northern Bulgarian Black Sea coast of Kavarna Town, Cape Kaliakra area. The slope is located about $4 \mathrm{~km}$ west of Cape Kaliakra. This region is composed of Miocene sediments, represented by the Euxinograd, Topola and Karvuna formations. The purpose of the study is to determine the current state of the slope, to make an engineering-geological characteristic of the sediments that compose it, as well as of the fallen eroded material. Although there are no large landslides in the area, this study is important for the assessment of geological hazards and their distribution along the coastline in this part of the Bulgarian Black Sea coast.

\section{BACKGROUND OF THIS STUDY}

The study area is located in northeastern Bulgaria, within the borders of the Moesian Platform, and more specifically within the borders of the Dobrudzha Plateau. Clayey and calcareous sediments were accumulated in the Varna-Balchik Depression during the early and middle Miocene. These sediments are divided into several formal lithostratigraphic units, of which, in the studied region, the Euxinograd, Topola and Karvuna formations are represented. They were described by different authors (e.g., Popov and Kojumdgieva, 1987; Koleva-Rekalova, 1994, 1997, 1998; Yaneva et al., 2019). 
The thickness of the Euxinograd Formation goes up to 100-110 m, between Kranevo Village and the town of Balchik. The upper part of the Euxinograd Formation is represented by an alternation of gray to dark gray diatomaceous-spongolithic clays and silty-sandy clays. The clays range from indistinct to fine-bedded. These sediments do not crop out in the studied area.

The sediments of the Topola Formation overlie the clays of the Euxinograd Formation and are covered by the limestones of the Karvuna Formation. The Topola Formation is predominantly composed of aragonite sediments, referred to as "aragonitites" by Koleva-Rekalova (1994). These rocks are gray and white to yellowish, laminated in the upper part and massive at the base of the profile. They are unconsolidated and microlaminated (laminae's thicknesses vary from $0.5 \mathrm{~mm}$ up $2-3 \mathrm{~mm}$ ). The aragonite sediments contain laterally persistent and thin (from 20-30 cm to $1 \mathrm{~m}$ ) layers of white, creamy and pale gray micritic limestones, which play a reinforcing role and are key contributors to the existence of vertical slopes in unaffected by sliding outcrops of the Topola formation (Evlogiev and Evstatiev, 2013; Lakov and Stoynev, 2013; Nankin and Krastanov, 2017; Lakov, 2018). The Karvuna Formation is composed of strong, dense Mactra limestones (12$15 \mathrm{~m}$ thick) that form the rock crown of the plateau.

Some of the largest landslides on the territory of Bulgaria are formed in the sediments of the Topola Formation, which crop out from the area south of the village of Kranevo to the town of Kavarna on the northern Bulgarian Black Sea coast (Varbanov et al., 1997; Frangov et al., 1998; Koleva-Rekalova et al., 1999; Berov et al., 2002, 2013; Lakov et al., 2002; Konstantinov et al., 2003; Evlogiev and Evstatiev, 2013; Nikolov and Atanasova, 2016; Evstatiev et al., 2017; Atanasova and Nikolov, 2019; Nankin and Ivanov, 2019). They are characterized by deep sliding surfaces (about $80 \mathrm{~m}$ ), most of which are in a conditionally stabilized state.

Rockfalls are common along several sectors on the coast. They occur mainly between the town of Kavarna and Cape Kaliakra and also north of Cape Kaliakra (the village of Kamen Bryag). Some rockfalls in this region probably had a seismic origin, triggered by powerful earthquakes with magnitude greater than 7 (Iliev, 1973; Konstantinov et al., 1992; Iliev-Broutchev, 1994).

The tectonic settings of the northern Bulgarian Black Sea coast are a prerequisite for high seismicity (Watzof, 1903; Dimitrov et al., 2017). Historical sources report large earthquakes that occurred during the Antiquity and the Middle Ages and caused landslides, rockfalls, floods and tsunamis
(Iliev, 1973; Dimitrov and Parlichev, 2014). The latest major disasters are related to the earthquake of 1901 with I = IX degree of MSK, whose epicenter was east of Cape Kaliakra at a depth of $8 \mathrm{~km}$. It caused a great destruction in the town of Kavarna and the surrounding villages. The effects of the Vrancea earthquake of 1977 on the landslides in the area of the northern Black Sea coast were examined by Brankov (1983). Active faults dating back to the Quaternary are also located near the town of Shabla and Cape Kaliakra. They are related to seismic activity in this part of the coast (Parlichev, 2014; Dimitrov et al., 2017). According to "The seismic zoning map of the Republic of Bulgaria for a 1000-year period”, the value of the seismic coefficient is 0.27 .

The studied area (composed of limestones and aragonite sediments) is characterized by low to medium velocity (intensity) of cliff erosion. For the area stretching between Kaliakra and Kavarna, the erosion rate is $0.01-0.20 \mathrm{~m} /$ year. The average height of the erosional cliff is $50 \mathrm{~m}$ and the relative quantity of eroded material is $0.5 \mathrm{~m}^{3}$ per year (Shuiskij and Simeonova, 1982). The factors forming the erosional cliff type in this region are denudation (weathering, erosion) and to a lesser extent wave activity (Shuiskij and Simeonova, 1982; Castedo et al., 2017). Under the effect of the non-wave factors, the weakly cohesive aragonite sediments of the Topola Formation reach a steep, almost vertical profile. The cliff face retreats not only due to wave erosion, but also the weathering processes and the sheet erosion of the water flowing through it. In the development of this type of cliffs, the role of linear abrasion is subordinate to the action of non-wave processes, so the shore is abraded at a low velocity. A coastal geo-protective facility (stone blocks and retaining wall) has been constructed in the Zelenka locality, designed to protect the coast from marine abrasion.

The climate features are of particular importance for the assessment of the weathering and erosion processes in the area. For the period from December to February, the average daily minimum temperatures are around zero and slightly below zero. The average daily maximum temperatures are $5-7^{\circ} \mathrm{C}$. In cold nights, the temperature is $-10^{\circ} \mathrm{C}$ to $-11^{\circ} \mathrm{C}$. Accordingly, rainfalls during these months are 40 $50 \mathrm{~mm}$ monthly on average. The prevailing winds in the area are from north and northeast, which in the winter reach speeds of $15-20 \mathrm{~m} / \mathrm{s}$.

\section{METHODOLOGY}

Engineering geological mapping was carried out in the area of the Zelenka locality. The amount of col- 
lapsed rock and earth masses, which belong to the sediments of the Topola Formation, were measured. The volume of these materials was determined for the period from October 2018 to March 2019 (four field observations in September, October 2018 and March, April 2019). Certain physical and classification characteristics of these materials were defined, such as grain size, plasticity and specific density, under BDS EN. For comparison, the plasticity index was also determined by the BDS 648 and 676 . The same parameters were defined for undisturbed material from the slope.

\section{RESULTS AND DISCUSSION}

In the measurements made on the collapsed earth and rock masses along a coastline segment (Fig. 1) with a length of about $680 \mathrm{~m}$, it was found that the affected areas had an overall length of $158.7 \mathrm{~m}$ divided into six sectors and the volume of collapsed masses amounted to $488.65 \mathrm{~m}^{3}$ (Table 1).

In the 63-meter almost vertical slope of Zelenka, the waters of the aquifer are discharged at an elevation of $36 \mathrm{~m}$ (Fig. 2). The eroded sectors are unevenly distributed along the coastline, most of which

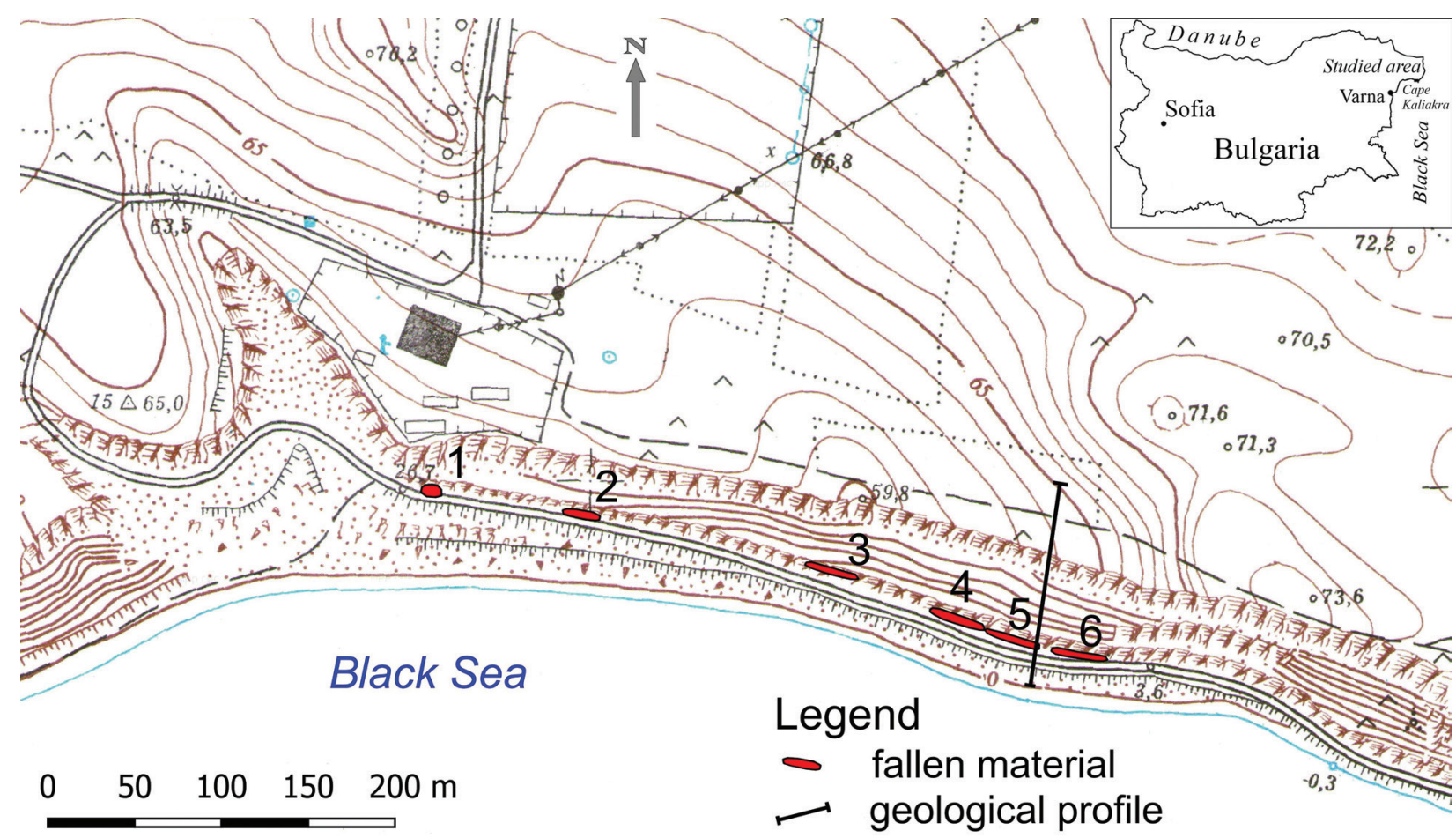

Fig. 1. Location of the fallen eroded rock and earth masses at the foot slope (sectors with numbers from 1 to 6) - Zelenka locality.

Table 1

Fallen rock and earth masses between September 2018 and March 2019

\begin{tabular}{|c|c|c|c|c|c|c|}
\hline \multirow{2}{*}{ No. } & \multirow{2}{*}{\multicolumn{2}{|c|}{$\begin{array}{l}\text { Coordinates in World Geodetic System } \\
\text { (WGS) } 1984\end{array}$}} & \multirow{2}{*}{$\frac{\text { Length }}{\mathrm{m}}$} & \multirow{2}{*}{$\frac{\text { Width }}{\mathrm{m}}$} & \multirow{2}{*}{$\frac{\text { Height }}{\mathrm{m}}$} & \multirow{2}{*}{$\frac{\text { Volume }}{\mathrm{m}^{3}}$} \\
\hline & & & & & & \\
\hline 1. & 43.38494 & 28.43092 & 13.4 & 6.4 & 2.2 & 94.76 \\
\hline 2. & 43.38488 & 28.43190 & 20.8 & 3.4 & 1.5 & 53.04 \\
\hline 3. & 43.38459 & 28.43368 & 30.5 & 0.9 & 1.0 & 13.73 \\
\hline 4. & 43.38430 & 28.43457 & 32.0 & 2.5 & 2.0 & 80.40 \\
\hline 5. & 43.38419 & 28.43497 & 30.0 & 2.5 & 1.9 & 72.00 \\
\hline \multirow[t]{2}{*}{6.} & 43.38411 & 28.43538 & 32.0 & 5.2 & 2.1 & 174.72 \\
\hline & & Total: & 158.7 & & & 488.65 \\
\hline
\end{tabular}

Note: The numbering is as shown in Fig. 1. 


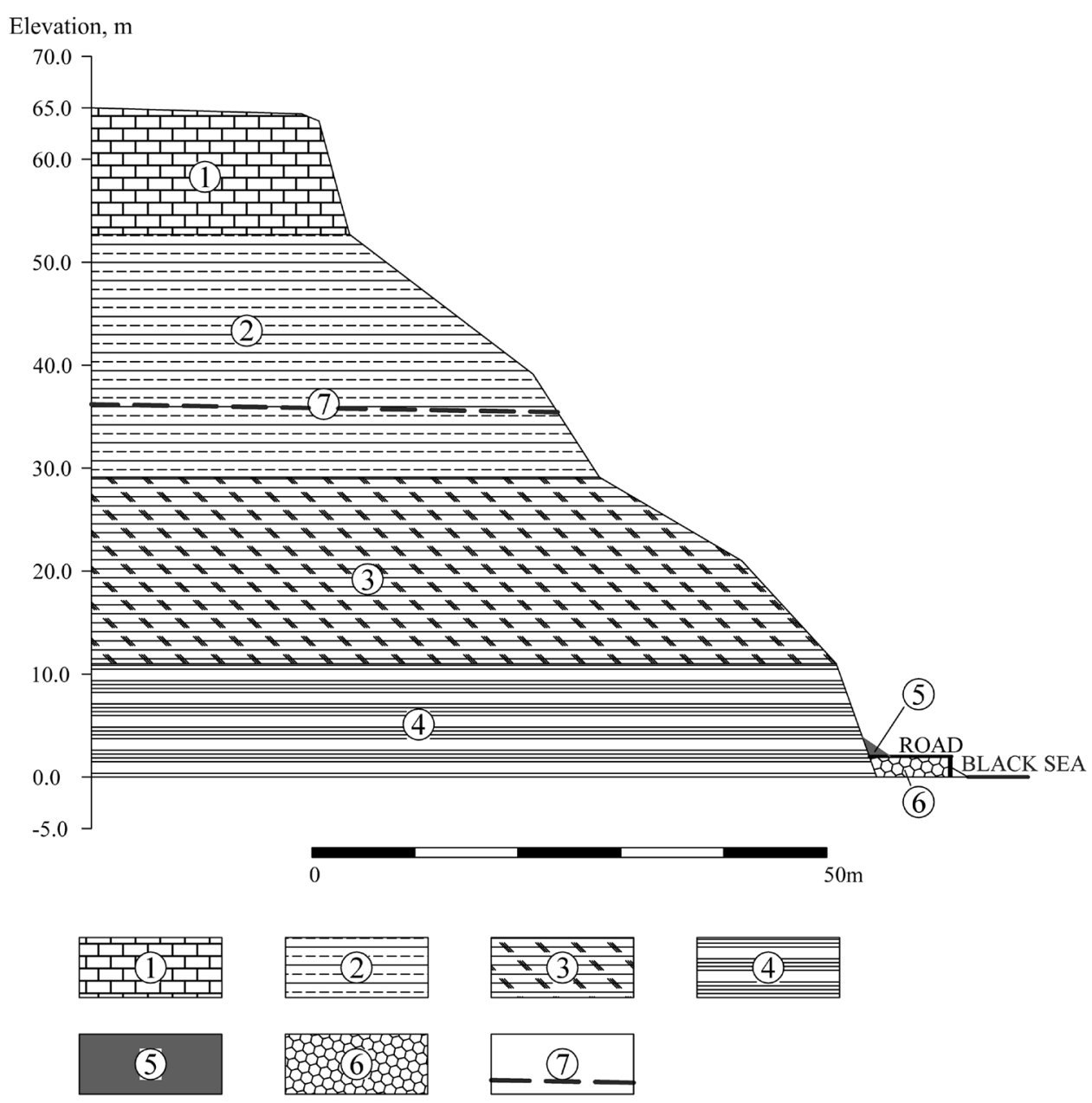

Fig. 2. Geological profile (the location is as shown in Fig. 1): 1 - limestone of the Karvuna Formation; 2 - limestone of the Topola Formation; 3 - aragonite sediments of the Topola Formation; 4 - aragonite sediments and clays of the Topola Formation; 5 - fallen eroded rock and earth masses; 6 - road embankment; 7 - groundwater level.

extend into the areas of abundant and continuous flowing water, and form small waterfalls in two locations.

The concentration of landslide and erosion processes in the areas of ground water discharge leads to the conclusion that the most likely cause of the bursts is the freezing of the waters in the voids of the sediments of the Topola Formation, which leads to the erosion of the slope surface. The fallen material barges the drainage ditch on the coastal road (Fig. 3), thus creating conditions for water retention. This leads to the infiltration of this water into the massif below the road and its waterlogging, which in turn will lead to a breakdown of road integrity.

The results of the laboratory tests for the fallen eroded material and the material collected from the slope show that the classification of soil, based on grading alone (BDS EN ISO 14688-2), for both soils is silt ( $\mathrm{Si}$ ) (Fig. 4, Table 2). The amount of fraction with size $<0.063 \mathrm{~mm}$ is $92.3 \%$ for the fallen eroded material and $95.4 \%$ for the material taken from the slope. The coefficient of uniformity $U_{c}$ is respectively 2.8 for the fallen eroded material and 8.1 for the material taken from the slope. The fallen eroded material is heterogeneous, mixed, including some gravels and cobbles. The plasticity index $I_{p}=$ $17.6 \%$ for the fallen eroded material and $I_{p}=34.1 \%$ for the material taken from the slope (BDS-EN ISO/ TS 17892-12).

The classification of soil, based on BDS 676-85, for both soils is silty sandy clay. This standard also takes into account the grain size distribution and the soil plasticity. The plasticity index (BDS 648) $I_{p}=$ $11.7 \%$ for the fallen eroded material and $I_{p}=16.3 \%$ for the material taken from the slope. 

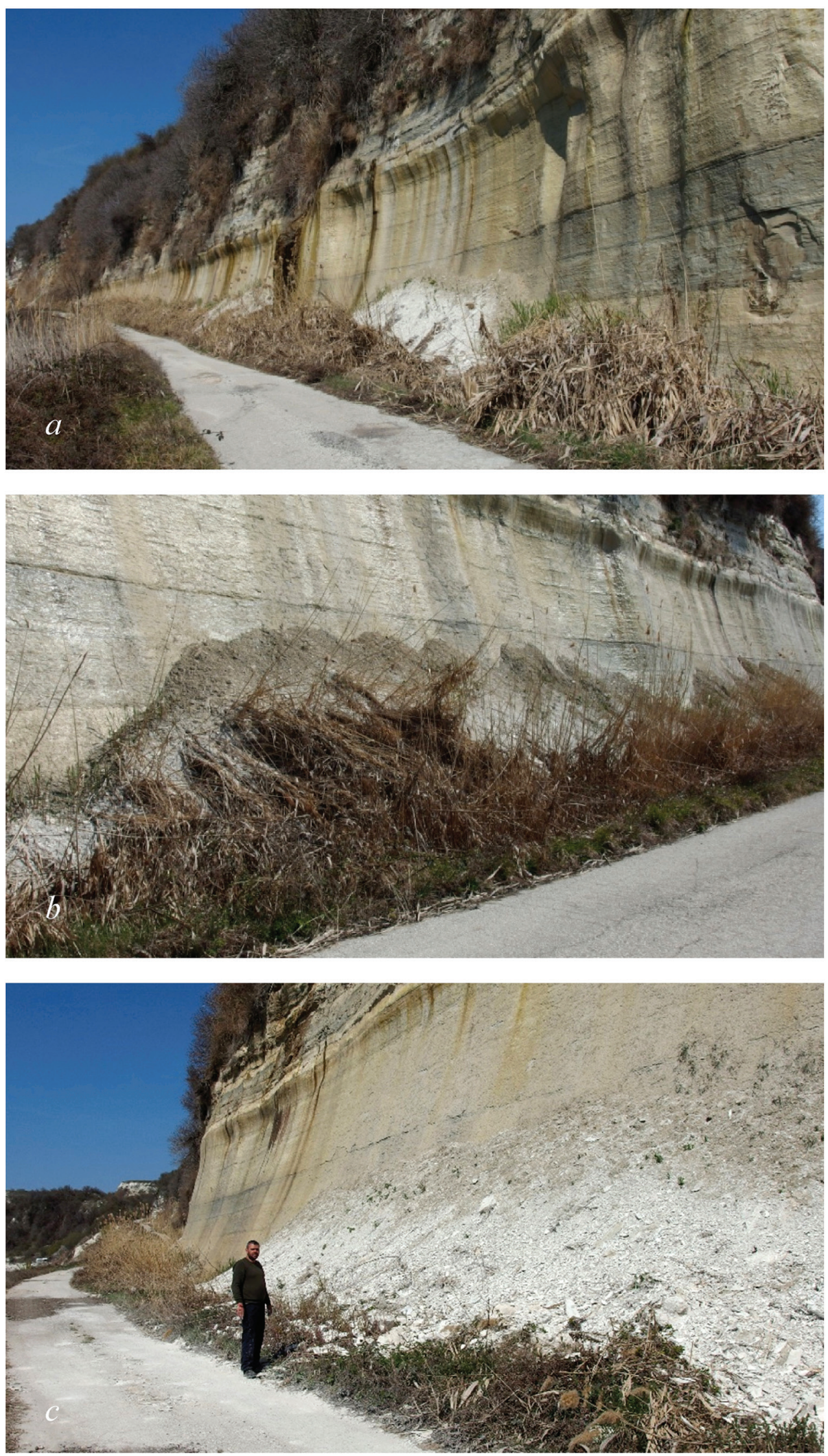

Fig. 3. Eroded material at the base of the slope - Zelenka locality, photo March 2019: $a$ ) eroded sector No. 2; $b$ ) eroded sector No. 3; c) eroded sector No. 5. 
PARTICLE SIZE DISTRIBUTION

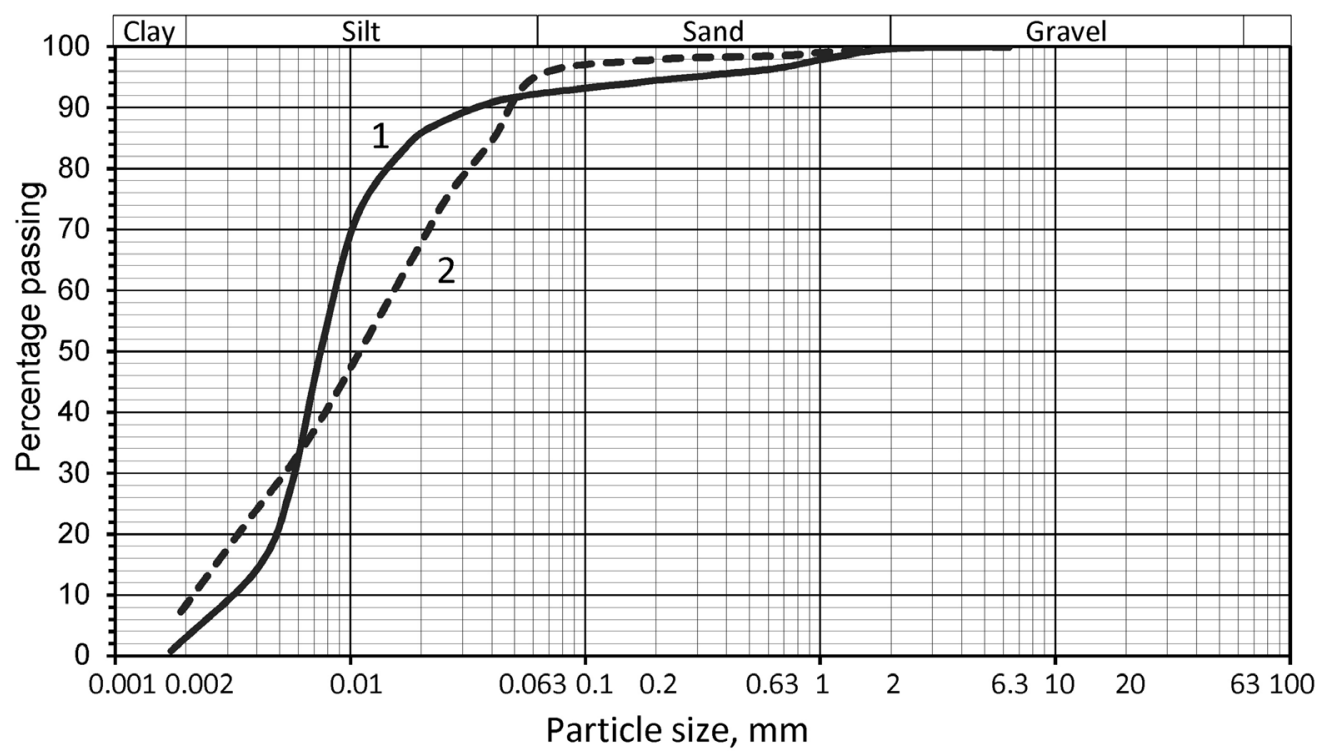

Fig. 4. Particle size distribution of the samples: 1 - fallen material below; 2 - undisturbed, from massif.

Table 2

Classification of soil, based on grading alone (BDS EN ISO 14688-2)

\begin{tabular}{lcccccc}
\hline \multirow{2}{*}{ Soil sample } & $\begin{array}{c}\text { Classification } \\
\text { of soil }\end{array}$ & $\% 2 \mathrm{~mm}$ & $2-0.063 \mathrm{~mm}$ & $<0.063 \mathrm{~mm}$ & $<0.002 \mathrm{~mm}$ & $U c$ \\
\cline { 3 - 7 } & Silt (Si) & 0.4 & 7.3 & 92.3 & 3.0 & 2.8 \\
\hline $\begin{array}{l}\text { fallen material } \\
\text { below }\end{array}$ & Silt (Si) & 0.1 & 4.5 & 95.4 & 8.5 & 8.1 \\
$\begin{array}{l}\text { undisturbed, } \\
\text { from massif }\end{array}$ & & & $\%$ & & $\%$ & - \\
\hline
\end{tabular}

Uc - coefficient of uniformity

\section{CONCLUSION}

The current study shows that, for the period from October 2018 to March 2019, the quantities of the eroded fallen materials from the slope composed of sediments of the Topola Formation in the area of the Zelenka locality is $489 \mathrm{~m}^{3}$. The length of the affected area is about $680 \mathrm{~m}$ and the total length of the fallen masses is $158.7 \mathrm{~m}$.

The laboratory tests indicate that the eroded material has lower plastic properties than the material taken from the slope. The soil classification based on BDS EN ISO 14688-2 is silt (Si). The classification of soil, according the old BDS 676-85, is silty sandy clay.

The fallen material blocks the drainage ditch at the base of the slope. In case they are not dealt with in a timely manner, these processes may damage the asphalt surface, which could lead to the road being closed next year.

\section{Acknowledgements}

This work has been carried out in the framework of the National Science Program "Environmental Protection and Reduction of Risks of Adverse Events and Natural Disasters", approved by the Resolution of the Council of Ministers No. 577/17.08.2018 and supported by the Ministry of Education and Science (MES) of Bulgaria (Agreement No. D01230/06.12.2018). We wish to thank two anonymous reviewers for their much-appreciated critical reviews and suggestions. 


\section{REFERENCES}

Atanasova, M., Nikolov, H. 2019. Application of interferometry in landslide area analysis. International Multidisciplinary Scientific GeoConference Surveying Geology and Mining Ecology Management, SGEM, 19 (5.2), 107-114.

Berov, B., Dobrev, N., Brouchev, I., Fukuzono, T. 2002. Landslides in Bulgaria. Journal of the Japan Landslide Society 38 (4), 334-343.

Berov, B., Ivanov, P., Dobrev, N., Nankin, R., Krastanov, M. 2013. State of the art for landslides along the North Bulgarian Black Sea coast. In: Margottini, Cl., Canuti, P., Sassa, K. (Eds), Landslide Science and Practice, Volume 5: Complex Environment. Springer, Heidelberg, New York, Dordrecht, London, 9-102.

Brankov G. (Ed.). 1983. The earthquake in Vrancha in 1977. Consequences in the Republic of Bulgaria. Bulgarian Academy of Sciences Academic Press, Sofia, 425 pp. (in Bulgarian, with English abstract).

Castedo R., Paredes, C., de la Vega-Panizo, R., Santos, A. 2017. The Modelling of Coastal Cliffs and Future Trends. In: Shukla, D. (Ed.), Hydro-Geomorphology - Models and Trends. IntechOpen, 53-78 (http://dx.doi.org/10.5772/intechopen.68445).

Dimitrov, O., Parlichev, D. 2014. Possible earthquake and tsunami foci before the Bulgarian coast of the Black Sea. Problems of Geography 3-4, 23-32 (in Bulgarian, with English abstract).

Dimitrov, O., Parlichev, D., Dobrev, N. 2017. Seismic and precursory aspect information about topography and tectonics of Bulgarian Black Sea coast. Engineering Geology and Hydrogeology 31, 13-23 (in Bulgarian, with English abstract).

Evlogiev, Y., Evstatiev, D. 2013. Landslides near the Topola village (Northern Black Sea coast). Engineering Geology and Hydrogeology 27, 13-69 (in Bulgarian, with English abstract).

Evstatiev, D., Evlogiev, Y., Nedelcheva, M. 2017. The landslides Zapadni Karamanlii and Momchilski Rid - Balchik Black Sea Coast. Review of the Bulgarian Geological Society 78 (1-3), 3-23 (in Bulgarian, with English abstract).

Frangov, G., Varbanov, R., Yordanova, J., Stakev, M. 1998. Contemporary landslide activity along Varna and Balchik sea coast. In: Marinski, J. (Ed.), Protection and long-term Stabilization of the Slopes of the Black Sea Coast. "Prof. Marin Drinov” Academic Press, Sofia, 20-29 (in Bulgarian, with English abstract).

Iliev I. 1973. Effect of the earthquakes on the appearance and activation of landslides along the Dobrudja Black Sea Coast. Review of the Bulgarian Geological Society 34 (1), 75-85 (in Bulgarian, with English abstract).

Iliev-Broutchev Il. (Ed.). 1994. Geological hazards in Bulgaria - Map in scale 1:500 000 and explanatory text. Military Topographic Service, Troyan/“Prof. Marin Drinov” Academic Press, Sofia, 143 pp. (in Bulgarian, with English Summary).

Koleva-Rekalova E. 1994. Sarmatian aragonite sediments in North-Eastern Bulgaria - origin and diagenesis. Geologica Balcanica 24 (5), 47-64.

Koleva-Rekalova, E. 1997. Sedimentological characteristics of the Sarmatian rocks in the Balchik area, Northeast Bulgaria. Review of the Bulgarian Geological Society 58 (1), 31-42 (in Bulgarian, with English abstract).
Koleva-Rekalova, E. 1998. Formational conditions of the Sarmatian sedimentary rocks from the Balchik area, NorthEastern Bulgaria. Review of the Bulgarian Geological Society 59 (1), 69-74 (in Bulgarian, with English abstract).

Koleva-Rekalova, E., Dobrev, N., Ivanov, P., Bozhinova, A. 1999. Sedimentological and engineering geological investigations of Sarmatian clays from the Balchik landslide region. Review of the Bulgarian Geological Society 60 (1-3), 103-108 (in Bulgarian, with English abstract).

Konstantinov, B., Angelov, K., Lakov, A., Stojnev, S., Konstantinov, V. 1992. Landslides activization from earthquake motions. Sixth International Symposium on Landslides (ISL 1992), 1181-1186.

Konstantinov, B., Lakov, A., Stoynev, S. 2003. Landslide hazard and risk in areas with predictable natural disasters. Proceedings of the National Scientific and Practical Conference "Preventive Activities for Limiting and Reducing the Consequences of Earthquakes and Landslides”, 186-194 (in Bulgarian).

Lakov, A. 2018. Rock slopes stability in open-pit mines and quarries. PhD thesis, University of Mining and Geology "St Ivan Rilski”, Sofia, 138 pp. (in Bulgarian, unpublished).

Lakov, A., Stoynev, S. 2013. Defining Hoek and Brown failure criterion for rocks from simple strength laboratory tests data. Proceedings of the XII National Conference of the open pit and underground mining of minerals, 218-225.

Lakov, A., Stoynev, S., Konstantinov, B. 2002. Geodynamic hazard and geodynamic risk along the Bulgarian Black Sea coast. Proceedings of the $9^{\text {th }}$ National Mine Surveying Conference with International Participation "Analysis, Modelling and Control of Geological Risk in Disturbed Territories", 263-268 (in Bulgarian).

Nankin, R., Ivanov, P. 2019. Current state of the landslides affecting the Northern Bulgarian Black Sea Coast. Review of the Bulgarian Geological Society 80 (3), 176-178 (in Bulgarian, with English abstract).

Nankin, R., Krastanov, M. 2017. Geotechnical parameters of limestone from the Topola Formation in the area of Topola Village, Kavarna Municipality. Geologica Balcanica 46 (2), 83-86.

Nikolov, H, Atanasova, M. 2016. Landslides monitoring near Kranevo by means of INSAR. Third European SCGIS Conference "Geoinformation technologies for natural and cultural heritage conservation", 54-63.

Popov, N., Kojumdgieva, E. 1987. The Miocene in Northeastern Bulgaria (lithostratigraphic subdivision and geological evolution). Review of the Bulgarian Geological Society 48 (3), 15-33 (in Bulgarian, with English abstract).

Shuiskij, J., Simeonova, G. 1982. On the type of abrasion cliffs along the Bulgarian Black Sea Coast. Engineering Geology and Hydrogeology 12, 11-21 (in Bulgarian, with English abstract).

Varbanov, R., Frangov, G., Evstatiev, D. 1997. The new destructive landslides to the north of Varna. Journal of Mining and Geology 5, 6-12 (in Bulgarian).

Watzof, S. 1903. Tremblements de terre en Bulgarie en 1901. Imprimerie de l'Etal, Sofia, 46 pp. (in Bulgarian).

Yaneva, M., Koleva-Rekalova, E., Nikolov, P., OgnjanovaRumenova, N. 2019. Topola Formation, Northeastern Bulgaria - biostratigraphical and palaeoecological aspects. Review of the Bulgarian Geological Society 80 (3), 133-135. 